УДК 339.162.4

JEL classification: M31

Зозульов О.В.

канд. економ. наук, професор

ORCID ID: 0000-0001-7087-2080

Василенко А.Т.

ORCID ID: 0000-0003-1237-7529

Національний технічний університет Украӥни

«Київський політехнічний інститут імені Ігоря Сікорського»

\title{
АНАЛІЗ ПОВЕДІНКИ СПОЖИВАЧІВ НА ПРОМИСЛОВОМУ РИНКУДЛЯ ФОРМУВАННЯ ТОРГОВОЇ ПРОПОЗИЩЇ̈
}

\section{АНАЛИЗ ПОВЕДЕНИЯ ПОТРЕБИТЕЛЕЙ НА ПРОМЫШЛЕННОМ РЫНКЕ ДЛЯ ФОРМИРОВАНИЯ ТОРГОВОГО ПРЕДЛОЖЕНИЯ}

\section{ANALYSIS OF CONSUMER BEHAVIOR IN THE INDUSTRIAL MARKET TO FORM A TRADE OFFERS}

В статті наведене та проаналізоване питання формування значущої пропозиції на промисловому ринку, висвітлено основні проблеми з якими стикається українське підприємство при ї розробиі, а також причини їх виникнення. В статті наведена методика побудови унікальної торгової пропозиції, представлена у вигляді 4-х етапної схеми, щуо включає пошук відповідей на питання n'яти основних блоків: «цільова аудиторія», «иінність», «переваги», «конкуренція», "результат діяльності».Виявлено, щяо недостатня увага приділяється аналізу ринкового середовища клієнта, дослідженню специфіки роботи в його галузі, особливостям організації клієнта. На основі факторів, щуо впливають на процес прийняття рішення про покупку на промисловому ринку в статті запропонована структурно-логічна схема аналізу споживачів для формування унікальної значущої для клієнта пропозииії. Запропонований у статті хід дослідження та отримані результати можуть стати для підприємства відчутною перевагою у конкурентній боротьбі за клієнта.

Ключові слова: маркетинг, унікальна торгова пропозиція, поведінка споживача на промисловому ринку

В статье приведень и проанализированы вопросы формирования значимого предложения на промышленном рынке, освещены основные проблемы, с которыми сталкивается украинское предприятие при его разработке, а также причины их возникновения. В статье приведена методика построения уникального торгового предложения, представленная в виде 4-х этапной схемы, включающей поиск ответов на вопросы пяти основных блоков: «целевая аудитория», «иенность», «преимущества», «конкуренция», «результат деятельности». Выявлено, что недостаточное внимание уделяется анализу рыночной среды клиента, исследованию специфики работы в его отрасли, особенностям организации клиента. На основе факторов, влияющих на процесс принятия решения о покупке на промышленном рынке, в статье предложена структурнологическая схема анализа потребителей для формирования уникального значимого для клиента предложения. Предложенныи в статье ход исследования и полученные 
результаты могут стать для предприятия преимуществом в конкурентной борьбе за клиента.

Ключевые слова: маркетинг, уникальное торговое предложение, поведение потребителя на промышленном рынке.

The article describes and analyses the formation of meaningful offers in the industrial market, highlights the main problems facing the Ukrainian company in its development, as well as their causes. In the article the method of construction of a unique trade proposal, is presented in a 4stage scheme, including responses to questions of five main blocks: "target audience", "value", "advantage", "competition", "the result of work". Revealed that insufficient attention is paid to the analysis of the client's market environment, the specifics of its work in the specific sector of economics, especially poor attention is paid to the client's organization. Based on the factors influencing the decision-making process of buying on the industrial market in the article the logical-block diagram of analysis of consumers is presented to create a unique offer meaningful to the customer. Proposed in the article research and the results can be tangible benefits for businesses in competing for customers.

Keywords: marketing, unique selling proposition, consumer behaviour in the industrial market.

Вступ. Сучасна економічна ситуація в Україні характеризується високим ступенем глобалізації та інформатизації бізнесу, жорсткістю конкуренції та високими споживчими очікуваннями. Середовище сучасного бізнесу нестабільне та агресивне, важливим $є$ той факт, що внутрішній промисловий ринок обмежений, чутливий до цінових коливань i стає все менш рентабельним в багатьох сегментах. Особливо чутливо до нових реалій ведення бізнесу реагують підприємства, які працюють в сфері В2В-продажів, яким доводиться переглядати традиційні підходи до організації своєї діяльності, розробляти ефективніші методи пошуку клієнтів та заходи щодо їх утримання.

В цих умовах значна увага компаній підвищує вимоги до вибору постачальників і відповідно висуває для них все більш високі вимоги. Постачальники ресурсів стають для товаровиробника партнерами в реалізації стратегії організації виробництва, а якість ресурсів, що вони постачають, одним із чинників підвищення конкурентоспроможності продукції підприємства. I тому проблема вибору оптимального постачальника розглядається 3 точки зору багатьох аспектів діяльності компанії. Але відмінності між постачальниками стають менш помітними, адже вони постійно удосконалюються i розширяються умови придбання товарів i сервісів.

Питання вибору постачальників у сучасних умовах функціонування промислових підприємств досліджуються у багатьох наукових працях як вітчизняних - С. Крикавського, М.Окландера, О. Зозульова, так й зарубіжних вчених - Крістофера, Хєнфілда, Б. Роберта та інших. 
Зарубіжні вчені запропонували моделі поведінки покупця в промисловому середовищі й тактику, до якої можуть прибігати постачальники, прагнучі краще пристосуватися до різних ситуацій. Серед українських дослідників поведінки споживачів можна виділити О. Зозульова, Т. Царьову, Р. Іванову, О. Шафалюка.

Постановка завдання. Метою даної статті $є$ обгрунтування науковопрактичного підходу до аналізу контексту діяльності клієнта на промисловому ринку: факторів, що впливають на його рішення про здійснення покупки, внутрішні особливості, детермінанти, що формують ключові значущі критерії вбору постачальника. Метою даної статті є побудова логічно-структурної схеми аналізу клієнта для формування для нього значущої пропозиції.

Методологія. Теоретичною основою та методичною базою дослідження $\epsilon$ фундаментальні положення економічної теорії, сучасні концепції маркетингу, наукові праці вітчизняних та зарубіжних фахівців. Теоретикометодологічною основою проведеного дослідження стали загальнонаукові методи наукового пізнання: теоретичного узагальнення, систематизації, аналізу та синтезу.

Результати дослідження. Створення значущої пропозиції цінності для клієнта на В2В-ринку - один із ключових елементів побудови ефективної ринкової стратегії будь-якої компанії. Ця цінність може проявлятися у виготовленні продукту 3 найкращими техніко-економічними характеристиками, наданні повного клієнтського супроводу та підтримки, швидшої реакції на запити клієнтів та іншими параметрами, які можуть мати як реальне вираження, так і уявлення у свідомості клієнтів. В будь-якому випадку компанія прагне визначити свої переваги та відбудуватись на цьому базисі від конкурентів.

Проте, з точки зору, споживача пропозиції все більшої кількості компаній стають схожими одна на одну. Цьому сприяють, в першу чергу, мінімальне функціональні відмінності в запропонованих ринку товарах - навіть видатному продукту не вдасться втримати позиції лідера за функціональністю чи якістю виконання, адже швидкість копіювання та впровадження інновацій компаній-послідовників також 3 кожним роком стрімко розвивається. Іншою причиною, даного явища є високий рівень бар'єру донесення повідомлення про унікальну пропозицію через інформаційний шум та значне інформаційне навантаження. Таким чином, серед клієнтів формується сприйняття продуктів різних виробників як однакових, хоча між ними можуть існувати і помітні відмінності. Тому боротьба за увагу споживача стає складнішою, і $\epsilon$ своєрідним викликом.

Особливо це $\epsilon$ проблемним питанням для українського В2В-сектору, де перевага при формуванні пропозиції клієнту приділяється виключно 
технічним характеристикам запропонованого товару, а не актуалізації проблеми, яку вирішує даний товар або комплекс товарів та послуг. Відсутність розуміння клієнтського контексту діяльності, розуміння бізнес середовища, специфіки роботи в галузі, а також відстеження динаміки їх змін віддаляють компанії від формування пропозиції, що буде виділятись серед числа інших пропозицій на ринку.

Найбільш поширеним методом трансформування сильних та значущих параметрів діяльності компанії - це використання методу Unique Selling Proposition (УТП - унікальна торгова пропозиція) або Customer Value Proposition (ЗСП - значуща для споживача пропозиція).

УТП (Unique Selling Proposition) - це коротко сформульоване повідомлення про товар або всю компанія, яке виділяє їх з ряду аналогічних i служить для клієнта стимулом зробити покупку через фокусування уваги на вирішенні потреб та проблем споживача[1]. Прикладом успішно сформованої УТП є FedEx: «When it absolutely, positively has to be there over night» (Коли це точно повинно бути доставлено за одну ніч) [2]. Метод УТП відомий що з 40$\mathrm{x}$ років минулого сторіччя та пов'язаний із стратегією диференціації, ринковим позиціонуванням та просування товару на ринку.

ЗСП (Customer Value Proposition) - широко застосований останнім часом термін в межах клієнт-орієнтованої системи управління підприємством. Виділяють три підходи до визначення терміну «значущість (цінність) пропозиції»(“value proposition”), основні на: вигоді, диференціації та резонансі [8]. У першому випадку акцент робиться на вигодах, які отримує споживач, у другому - на ключових точках, що визначають відмінність нашої пропозиції відносно конкурентів, та у третьому -на чіткому розумінні потреб споживачів, знаходячись у резонансі з ними. Такий підхід передбачає зосередження на одній чи двох відмінностях (такий підхід відомий як DVP (distinctive value proposition) - відмінна ціннісна пропозиція), посилення яких наддасть найбільшу цінність для споживача в майбутньому.

Співвідносячи два терміни УТП та ЗСП потрібно відмітити, що поява останнього пов'язана із зміною концепції ведення бізнесу, його маркетингової філософії: відбувається перенесення акценту з виключно просування товару на аналіз значущих для споживача цінностей.

Процес формування значимої пропозиції можна зобразити у вигляді схеми, що зображена на рис. 1. 


\begin{tabular}{|c|c|c|c|c|}
\hline $\begin{array}{c}\text { Цільова } \\
\text { аудиторія }\end{array}$ & Цінність & Переваги & Конкуренція & $\begin{array}{l}\text { Результат } \\
\text { діяльності }\end{array}$ \\
\hline $\begin{array}{l}\text { Хто } \\
\text { нашим } \\
\text { клієнтом? } \\
\text { На якому } \\
\text { ринку він } \\
\text { працює? }\end{array}$ & $\begin{array}{l}\text { Що цінного ми } \\
\text { можемо } \\
\text { запропонувати } \\
\text { нашому клієнту? } \\
\text { Що є дійсно } \\
\text { цінним для } \\
\text { клієнта? Що є } \\
\text { цінним для інших } \\
\text { операторів ринку? }\end{array}$ & $\begin{array}{l}\text { Що ми можемо } \\
\text { запропонувати } \\
\text { краще, ніж наші } \\
\text { конкуренти? Які } \\
\text { унікальні } \\
\text { характеристики } \\
\text { містить наш } \\
\text { продукт/сервіс? } \\
\text { Чи можемо ми } \\
\text { вдосконалити } \\
\text { продукт? }\end{array}$ & $\begin{array}{l}\text { Які } \\
\text { продукти/сервіси } \\
\text { пропонують ринку } \\
\text { наші } \quad \text { прямі } \\
\text { конкуренти? Як ми } \\
\text { можемо нівелювати } \\
\text { їх пропозицію? }\end{array}$ & $\begin{array}{l}\text { Як ми } \\
\text { отримаємо } \\
\text { прибуток } 3 \\
\text { нашої } \\
\text { пропозиції? }\end{array}$ \\
\hline & & & \multicolumn{2}{|c|}{$\begin{array}{l}\text { Що ми б сказали нашому клієнту під } \\
\text { час так званого Elevator Pitch - } \\
\text { короткої розповіді про концепцію } \\
\text { продукту, проекту або сервісу, що } \\
\text { триває близько тридцяти секунд або } \\
\text { 100-150 слів - за аналогією стільки } \\
\text { ви можете сказати під час поїздки в } \\
\text { ліфті. }\end{array}$} \\
\hline
\end{tabular}

Рис. 1. Формування значимої пропозиції для клієнта на промисловому ринку [4, доповнено авторами]

Виходячи із наведеного метод побудови УТП[3] з врахуванням методу ЗСП [4] має передбачати такі вісім етапів:

1. Визначити нашу цільову аудиторію.

2. Визначити, що ми можемо їй запропонувати.

3. Визначити основні характеристики товару компанії.

4. Визначити переваги та вигоди від нашого товару/компанії для цільової аудиторії.

5. Перевірити ці переваги на значимість для конкретних клієнтів.

6. Визначити, що ми будемо говорити споживачеві у разі несприйняття ним цих переваг під час знайомства $з$ товаром.

7. Визначити як виходячи з цього ми будемо отримувати прибуток. 
8. Обрати найбільш значимі та унікальні переваги та сформувати 3 них коротке чітке повідомлення для споживача, яке буде доноситися за допомогою комплексу маркетингових комунікацій.

Побудову сильної пропозиції можна сформувати у вигляді відповідей на низку питань, які дозволять виділити сильні сторони компанії, цінність, яку компанія привносить на ринок, а також сформувати коротке повідомлення, яке буде доносити клієнту пропозиції вирішення його бізнес-потреб. Проте, як вже було зазначено раніше, проблемних аспектів діяльності українських компаній, на практиці виходить, що формування пропозиції здійснюється виключно після проходження першого етапу і відразу переноситься на впровадження до комплексу маркетингових комунікацій. Ще одним варіантом $\epsilon$ такий, коли компанії використовують невиразні та розмиті ринкові кліше та стереотипи, вибіркове висвітлення результатів діяльності та інше, одначе ні слова про самого клієнта, «вузькі місця» в його діяльності.

Недостатня увага кроку 3 та 4 пов'язана із недооціненням важливості отриманої інформації у порівнянні із використанні ресурсів ( як людських, так і фінансових) для їі отримання, компанія використовує напрацьовану модель пропозиції, яка могла втратити свою актуальність для клієнта в виду появи та трансформації пропозиції на ринку інших компаній-конкурентів.

Щоб визначити релевантність та значимість запропонованих переваг для клієнта необхідно:

- розуміти середовище в якому працює клієнт - мати уявлення про динаміку та тенденції на ринку клієнта, структурні зміни по ланцюжку продажів;

- знатися на особливостях потреб клієнта, специфіки його роботи в рамках визначеної внутрішньої структури компанії клієнта;

- мати чітке уявлення про систему критеріїв та їх значимість при виборі потенційного постачальника.

Для володіння визначеним переліком даних підприємству необхідно здійснювати постійний моніторинг змін та застосовувати прогностичні моделі для відбудови стабільної довгострокової пропозиції.

Проведені раніше дослідження дають нам розуміння того, що поведінка споживача на промисловому ринку обумовлена групою факторів, що впливають на процес прийняття рішення про покупку - рис.2, а також пов'язана 3 2-ма головними обмеженнями цих ринків - чим вище рівень цінності, тим більш абстрактно вона звучить і тим менше до неї довіри, в силу своєї природи, другим чинником є те, що закупівельні центри в В2В мають різні інтереси і переслідують різні вигоди. 


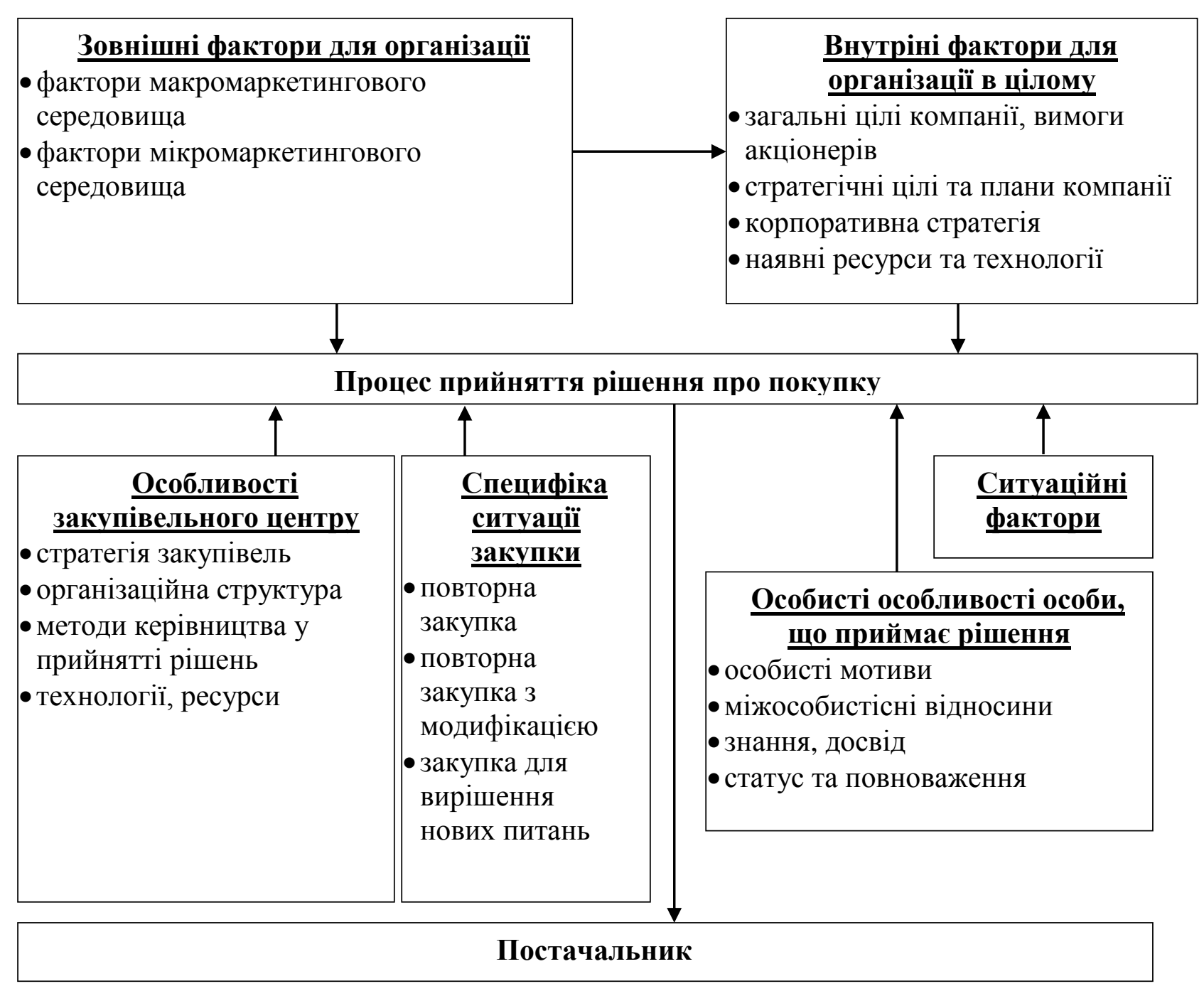

Рис. 2. Фактори, що впливають на процес прийняття рішення про покупку на промисловому ринку [5]

Приймаючи до уваги дані фактори, ми можемо запропонувати модель дослідження профілю цільового компанії-споживача для визначення найбільш важливих критерії та їх значення - рис. 3 . 


\begin{tabular}{|c|c|c|c|c|c|}
\hline Назва етапу & \multicolumn{5}{|c|}{$\begin{array}{c}1 \text { етап } \\
\text { Проведення ознайомлення з компанією, товаром, історію роботи компанії, отримання довідки про власників та } \\
\text { керівників компанії, ретроспективний аналіз динаміки ринку }\end{array}$} \\
\hline \multirow[b]{2}{*}{$\begin{array}{c}\text { Що } \\
\text { досліджусмо }\end{array}$} & \multicolumn{5}{|c|}{ Визначення: } \\
\hline & \multicolumn{5}{|c|}{$\begin{array}{c}\text { рівня } \\
\text { конкуренції на ринк } \\
\text { (зрілість ринку, поточна ситус } \\
\text { ринкова сила конкуруючих комп } \\
\text { конкурентної боротьби, форма }\end{array}$} \\
\hline Назва етапу & \multicolumn{3}{|c|}{$\begin{array}{c}\text { 2 етап } \\
\text { Визначення на основі чого компанія конкурує на ринку. } \\
\text { Визначення шляхів отримання конкурентних переваг та способів їх реалізації: }\end{array}$} & \multirow{5}{*}{ 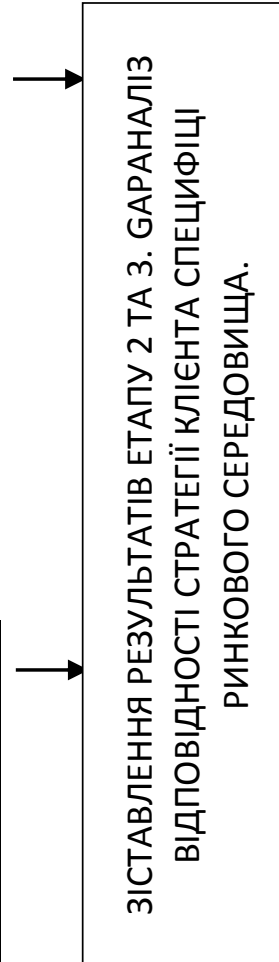 } & \multirow{5}{*}{ 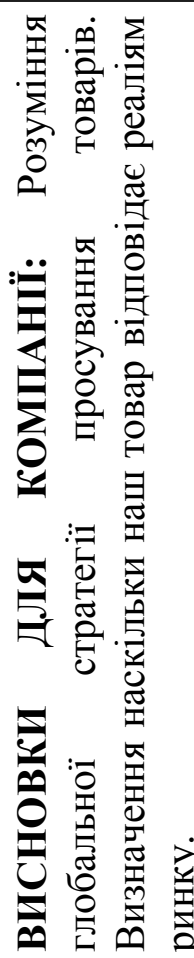 } \\
\hline $\begin{array}{c}\text { Що } \\
\text { досліджуємо }\end{array}$ & \begin{tabular}{l|l} 
конкурента & $\begin{array}{c}\text { стати краще самому - } \\
\text { здійснення сукупності } \\
\text { заходів для покращення } \\
\text { середовища }\end{array}$ \\
$\begin{array}{c}\text { діяльності компанії за } \\
\text { рахунок лідерства за }\end{array}$
\end{tabular} & \multicolumn{2}{|c|}{$\begin{array}{c}\text { стати краще самому - } \\
\text { здійснення сукупності } \\
\longrightarrow \text { заходів для покращення } \\
\text { діяльності компанії за } \\
\text { рахунок лідерства за }\end{array}$} & & \\
\hline Назва етапу & \multicolumn{3}{|c|}{$\begin{array}{l}\mathbf{3} \text { етап } \\
\text { Аналіз стратегічного бачення компанії на ринку: } \\
\end{array}$} & & \\
\hline $\begin{array}{c}\text { Що } \\
\text { дослліджуємо }\end{array}$ & $\begin{array}{c}\text { визначення вектору розвитку компанії, iї } \\
\text { місії на ринку }\end{array}$ & $\begin{array}{l}\text { розуміння } \\
\text { розвитку } \\
\text { ринку }\end{array}$ & $\begin{array}{l}\text { усвідомлення } \\
\text { сильних та слабких } \\
\text { сторін компанії }\end{array}$ & & \\
\hline $\begin{array}{c}\text { Мета } \\
\text { аналізу }\end{array}$ & \multicolumn{3}{|c|}{ УСВІДОМЛЕННЯ СТРАТЕГІЇ КОМПАНІЇ-КЛІЄНТА } & & \\
\hline
\end{tabular}




\begin{tabular}{|c|c|c|c|c|c|c|c|c|}
\hline Назва етапу & \multicolumn{6}{|c|}{$\begin{array}{c}\mathbf{3} \text { етап } \\
\text { Аналіз моделі поведінки компанії-клієнта }\end{array}$} & \multirow{3}{*}{$\rightarrow$} & \multirow{3}{*}{ 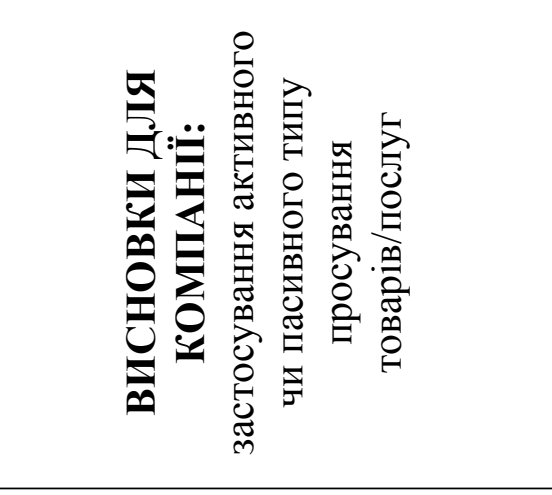 } \\
\hline $\begin{array}{c}\text { Що } \\
\text { досліджусмо }\end{array}$ & \multicolumn{2}{|c|}{$\begin{array}{c}\text { стиль керівництва } \\
\text { (авторитарний, демократичний, } \\
\text { ліберальний) }\end{array}$} & \multicolumn{2}{|c|}{$\begin{array}{c}\text { особливості осіб, що беруть } \\
\text { участь в процесі закупки } \\
\text { (схильність до ризику, } \\
\text { особисті мотиваиії, } \\
\text { посадові обов'язки та } \\
\text { повноваження) }\end{array}$} & \multicolumn{2}{|c|}{$\begin{array}{c}\text { характер } \\
\text { інноваційної } \\
\text { політики }\end{array}$} & & \\
\hline $\begin{array}{c}\text { Мета } \\
\text { аналізу }\end{array}$ & \multicolumn{6}{|c|}{ ВИЗНАЧЕННЯ ТИПУ ПОВЕДІНКИ З КЛІЄНТАМИ (АКТИВНИЙ / ПАСИВНИЙ) } & & \\
\hline Назва етапу & \multicolumn{6}{|c|}{4 етап } & \multirow{3}{*}{$\rightarrow$} & \multirow{3}{*}{ 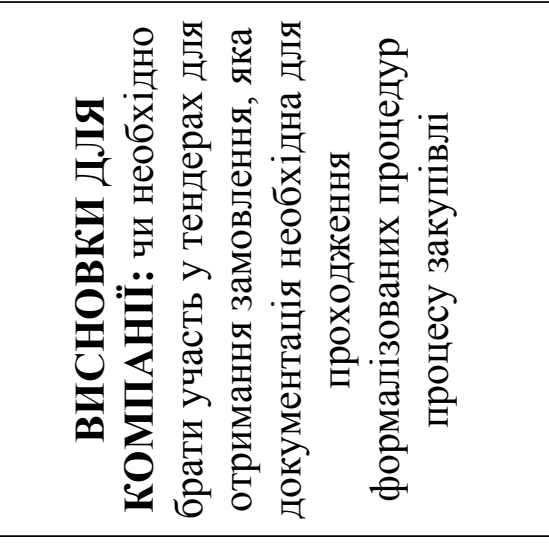 } \\
\hline $\begin{array}{c}\text { Що } \\
\text { досліджусмо }\end{array}$ & $\begin{array}{l}\text { тип власності } \\
\text { (державна, } \\
\text { приватна, } \\
\text { комунальна) }\end{array}$ & $\begin{array}{c}\text { етап життєвого } \\
\text { циклу компанії } \\
\text { за Юдановим- } \\
\text { Раменським } \\
\text { (ластівки, миші, } \\
\text { лиси, леви, } \\
\text { бегемоти, слони) }\end{array}$ & $\begin{array}{c}\text { тип } \\
\text { закупівельної } \\
\text { ситуації } \\
\text { (нова закупка, } \\
\text { закупка з } \\
\text { модифікаціями, } \\
\text { закупка без } \\
\text { змін) } \\
\end{array}$ & $\begin{array}{r}\text { наявніст } \\
\text { закупівель } \\
\text { центру } \\
(\epsilon / \text { немає }\end{array}$ & ого & $\begin{array}{c}\text { наявність } \\
\text { відділу } \\
\text { закупок } \\
( \\
\text { є/немає) }\end{array}$ & & \\
\hline $\begin{array}{c}\text { Мета } \\
\text { аналізу }\end{array}$ & \multicolumn{6}{|c|}{$\begin{array}{c}\text { ВИЗНАЧЕННЯ РІВНЯ ФОРМАЛІЗАЦІЇ ПРОЦЕСУ ПРИЙНЯТТЯ РІШЕННЯ ПРО } \\
\text { ПОКУПКУ }\end{array}$} & & \\
\hline Назва етапу & \multicolumn{6}{|c|}{5 етап } & \multirow{3}{*}{$\rightarrow$} & \multirow{3}{*}{ 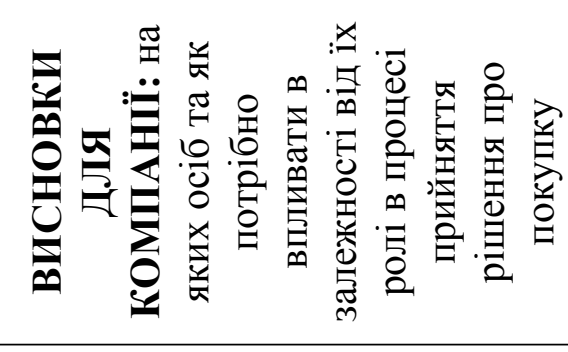 } \\
\hline $\begin{array}{c}\text { Що } \\
\text { досліджуємо }\end{array}$ & \multicolumn{2}{|c|}{ організаційна структура компанії } & $\begin{array}{c}\text { стиль } \\
\text { управління }\end{array}$ & \multicolumn{3}{|c|}{\begin{tabular}{|c|} 
прийняті в компанії \\
методи та процедури \\
процесу прийняття \\
рішення про покупку
\end{tabular}} & & \\
\hline $\begin{array}{c}\text { Мета } \\
\text { аналізу }\end{array}$ & \multicolumn{6}{|c|}{$\begin{array}{c}\text { ВИЗНАЧЕННЯ СУБ'СКТНОСТІ: ВИЗНАЧЕННЯ ОСІБ, ЩО ПРИЙМАЮТЬ } \\
\text { ОСТАТОЧНЕ РІШЕННЯ }\end{array}$} & & \\
\hline
\end{tabular}




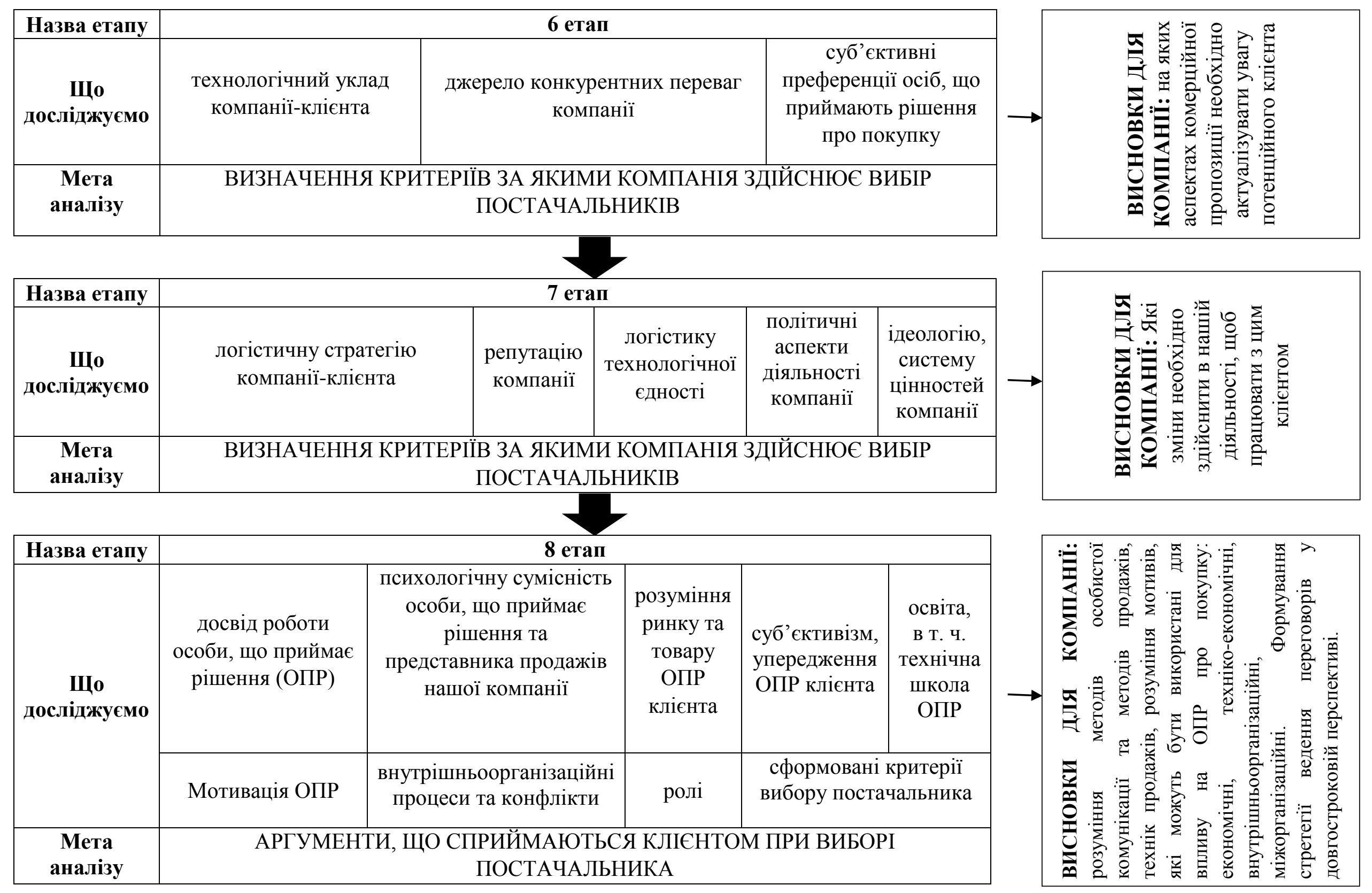

Рис. 3. Структурно-логічна схема дослідження потенційного клієнта на промисловому ринку для формування унікальної торгової пропозиції (авторська розробка) 
Висновки. Отже, наукова новизна отриманих результатів полягає систематизації та розширенні підходів до формування унікальної значущої пропозиції на В2В ринку з урахуванням специфіки поведінки промислового споживача та дослідження контексту діяльності, а також формуванні структурно-логічної схеми дослідження потенційного клієнта на промисловому ринку для формування унікальної значущої пропозиції.

Розуміння контексту діяльності клієнта дає компанії переваги у конкурентній боротьбі. Дослідження клієнта дасть розуміння процесу вибору та пріоритизації критерії вибору постачальника. Результати аналізу за запропонованою структурно-логічною схемою повинно стати основою при розробці загальної стратегії розвитку компанії, а в першу чергу коригування комунікаційної стратегії. Виявлення ключових важливих цінностей для клієнта повинно стати основою внутрішніх та зовнішніх комунікацій. Релевантне повідомлення стане ефективним способом оптимізації витрат на залучення нових клієнтів та утримання існуючих.

\section{Література:}

1. Уникальное торговое предложение (УТП): правила разработки от А до Я. [Електронний ресурс] - Режим доступу: http://www.gd.ru/articles/3714-unikalnoetorgovoe-predlojenie-utp

2. Creating a unique selling proposition - [Електронний ресурс] - Режим доступу: http://www.slideshare.net/mistykortes/creating-a-unique-selling-proposition

3. Каксформулироватьсильноепредложениеценности. Методика построенияключевых сообщений для B2B. B2B Ray. - [Електронний ресурс] - Режим доступу: http://www.slideshare.net/evgeniyvoropay/kak-sformulirovat

4. Marketing Strategy: What Makes You Special? - [Електронний ресурс] - Режим доступу: https://www.b2binternational.com/publications/marketing-strategy-what-makesyou-special/

5. Зозулёв А. В. Промышленный маркетинг : рыночная стратегия : учеб. пособие / А. В. Зозулёв. - К. : ЦУЛ, 2010. - 576 с.

6. Зозульов О. Критерії ефективного ринкового позиціонування товарів на споживчому ринку //Маркетинг в Україні. - 2015. - № 2 (89). - С. 39-45.

7. Царьова Т. О. Підходи до аналізу поведінки промислових споживачів // Маркетинг в Україні. - К., - 2006 - № 3 (37). - С. 16-19.

8. C. Anderson, James A. Narus, Wouter van Rossum. Customer Value Propositions in Business Markets- [Електронний pecypc] - Режим доступу: http://www.academia.edu/10395145/Customer_Value_Propositions_in_Business _Markets 